\title{
Quebec's Multi-Party Observatory on Zoonoses and Adaptation to Climate Change
}

G Germain ${ }^{1 *}$, A Simon², J Arsenault², G Baron ${ }^{3}$, C Bouchard ${ }^{4}$, D Chaumont ${ }^{5}$, F El Allaki , A Kimpton 1 , B Lévesque 7 , A Massé ${ }^{8}$, M Mercier 9 , NH Ogden ${ }^{4}$, I Picard ${ }^{10}$, A Ravel ${ }^{2}$, JP Rocheleau $^{2}$, J Soto $^{1}$ for Quebec's Multi-Party Observatory on Zoonoses and Adaptation to Climate Change

\begin{abstract}
Climate change has been linked with the establishment and geographical expansion of zoonotic diseases, an example of which is the well-documented increase in human cases of Lyme disease in Quebec, Canada. As temperatures continue to increase in Quebec, it is anticipated that several zoonotic diseases will be affected. In response to the growing zoonotic issues facing public health authorities, Quebec's Multi-Party Observatory on Zoonoses and Adaptation to Climate Change (Observatoire multipartite québécois sur les zoonoses et I'adaptation aux changements climatiques) (the Observatory) was founded in 2015 as part of the Quebec government's Climate Change Action Plan (Plan d'action 2013-2020 sur les changements climatiques). The Observatory was designed to bring together agencies involved in formulating public policy and experts from the disciplines of human health, animal health and environmental sciences, in a manner similar to the innovative "One World, One Health" approach. The Observatory provides a platform for knowledge sharing and consensus building among representatives of public policy decision makers and scientists. Its main objectives are to anticipate and prioritize potential issues associated with zoonotic diseases in Quebec, in order to support applicable risk management and climate change adaptation. This article describes what the Observatory is, what it does and outlines its plans for the future.
\end{abstract}

Suggested citation: Germain G, Simon A, Arsenault J, Baron G, Bouchard C, Chaumont D, El Allaki F, Kimpton A, Lévesque B, Massé A, Mercier M, Ogden NH, Picard I, Ravel A, Rocheleau JP, Soto J. Quebec's Multi-Party Observatory on Zoonoses and Adaptation to Climate Change. Can Commun Dis Rep 2019;45(5):143-8 https://doi.org/10.14745/ccdr.v45i05a05

Keywords: adaptation, climate change, Observatory, One Health, zoonoses, zoonotic diseases, prioritization, anticipation

\section{Introduction}

According to the World Health Organization, climate change is the greatest single threat to human health in the $21^{\text {st }}$ century (1). This threat has been linked to increases in chronic diseases, health problems related to extreme heat or floods, food shortages due to drought or flooding, smog- and pollen-related respiratory problems and a possible increase in conditions related to exposure to ultraviolet radiation (2). Climate change has also been shown to play a role in the establishment and geographic expansion of zoonotic diseases. Zoonotic diseases are defined as diseases or infections that are caused by viruses, bacteria, parasites, fungi or prions, and that can be transmitted between humans and animals (3). Zoonoses account for $60 \%$ of emerging infectious diseases and their significance in terms of global health is steadily increasing (4).

Climate change has been shown to result in warming temperatures and increasing precipitation, both of which influence the survival and spread of the zoonotic pathogens and/or the reproductive rate and geographic distribution of their vectors (5). Activities that extend the duration of transmission of zoonoses, as well as those that facilitate human exposure to the environment and thus to vectors and their associated pathogens, are also likely to be affected by climate change (5).
This work is licensed under a Creative Commons Attribution 4.0 International License.

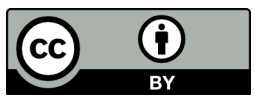

Affiliations

${ }^{1}$ Direction des risques biologiques et de la santé au travail, Institut national de santé publique du Québec, Montréal, $\mathrm{QC}$

${ }^{2}$ Groupe de recherche en épidémiologie des zoonoses et en santé publique, Faculté de médecine vétérinaire - Université de Montréal, St. Hyacinthe, QC

${ }^{3}$ Direction de la santé publique, Centre intégré universitaire de santé et de services sociaux de l’Estrie-Centre hospitalier universitaire de Sherbrooke, Sherbrooke, QC

${ }^{4}$ National Microbiology Laboratory, Public Health Agency of Canada, St. Hyacinthe, QC

${ }^{5}$ Climate Scenarios and Services Program, Ouranos, Montreal, QC

${ }^{6}$ Terrestrial Animal Health Epidemiology \& Surveillance Section, Animal Health Science Directorate, Canadian Food Inspection Agency, St. Hyacinthe, $\mathrm{QC}$

${ }^{7}$ Direction de la santé environnementale et de la toxicologie, Institut national de santé publique du Québec, Québec City, QC

${ }^{8}$ Direction de l'expertise sur la faune terrestre, l'herpétofaune et l'avifaune, ministère des Forêts, de la Faune et des Parcs, Québec City, QC

${ }^{9}$ Direction de la vigie sanitaire, ministère de la Santé et des Services sociaux, Montréal, QC

${ }^{10}$ Direction de la santé animale, ministère de l'Agriculture, des Pêcheries et de I'Alimentation, Québec City, QC

*Correspondence:

genevieve.germain@inspq.qc.ca 
In Quebec, average annual temperatures have increased between $1^{\circ} \mathrm{C}$ and $3^{\circ} \mathrm{C}$ since 1950 and are expected to increase by an additional $2^{\circ} \mathrm{C}$ to $4^{\circ} \mathrm{C}$ by 2050 (6). Monitoring of zoonoses in Quebec has shown an increase in human cases of zoonotic diseases, including Lyme disease (7). Ixodes scapularis, the primary tick vector of Lyme disease in North America, has gained between 35 and $55 \mathrm{~km}$ of geographic expansion each year in Canada, and this expansion has been clearly linked to climate change (8). An increase in the habitat of tick populations across Canada is likely to result in an increase in contact between humans and ticks (and tick-borne diseases) (9). Overall, the effects of climate change on zoonoses are poorly understood and challenging to predict, due to the complexity of their ecology and to the varying impacts of climate change upon them (10).

The aim of Quebec's Multi-Party Observatory on Zoonoses and Adaptation to Climate Change (Observatoire multipartite québécois sur les zoonoses et l'adaptation aux changements climatiques) (the Observatory) is to assess zoonotic diseases, to monitor trends and to educate and advise policy makers on how to address these infectious diseases, particularly in relation to how these zoonoses and their associated pathogens respond to climate change. The Observatory was founded in 2015 as a part of the government of Quebec's 2013-2020 Climate Change Action Plan, which mandated the Ministry of Health and Social Services to develop the action plan's health-related components. The objective of this article is to identify what the Observatory is, what it does and to outline its plans for the future.

\section{What the Observatory is}

The Observatory is a collaboration of scientific experts and public policy makers across the province of Quebec (Figure 1). It has a unique organizational structure that follows the innovative "One World, One Health" approach (11). This approach is defined as the "collaborative efforts of multiple disciplines working locally, nationally and globally to achieve optimal health for people, animals and our environment" (12). The Observatory enables this collaboration through discussions and knowledge transfer among members specializing in three areas of expertise: human health; animal health; and environmental science. The Observatory structures and streamlines the networking of members through regular meetings and through a range of deliverables.

Figure 1: The Observatory's "One World, One Health" organizational structure

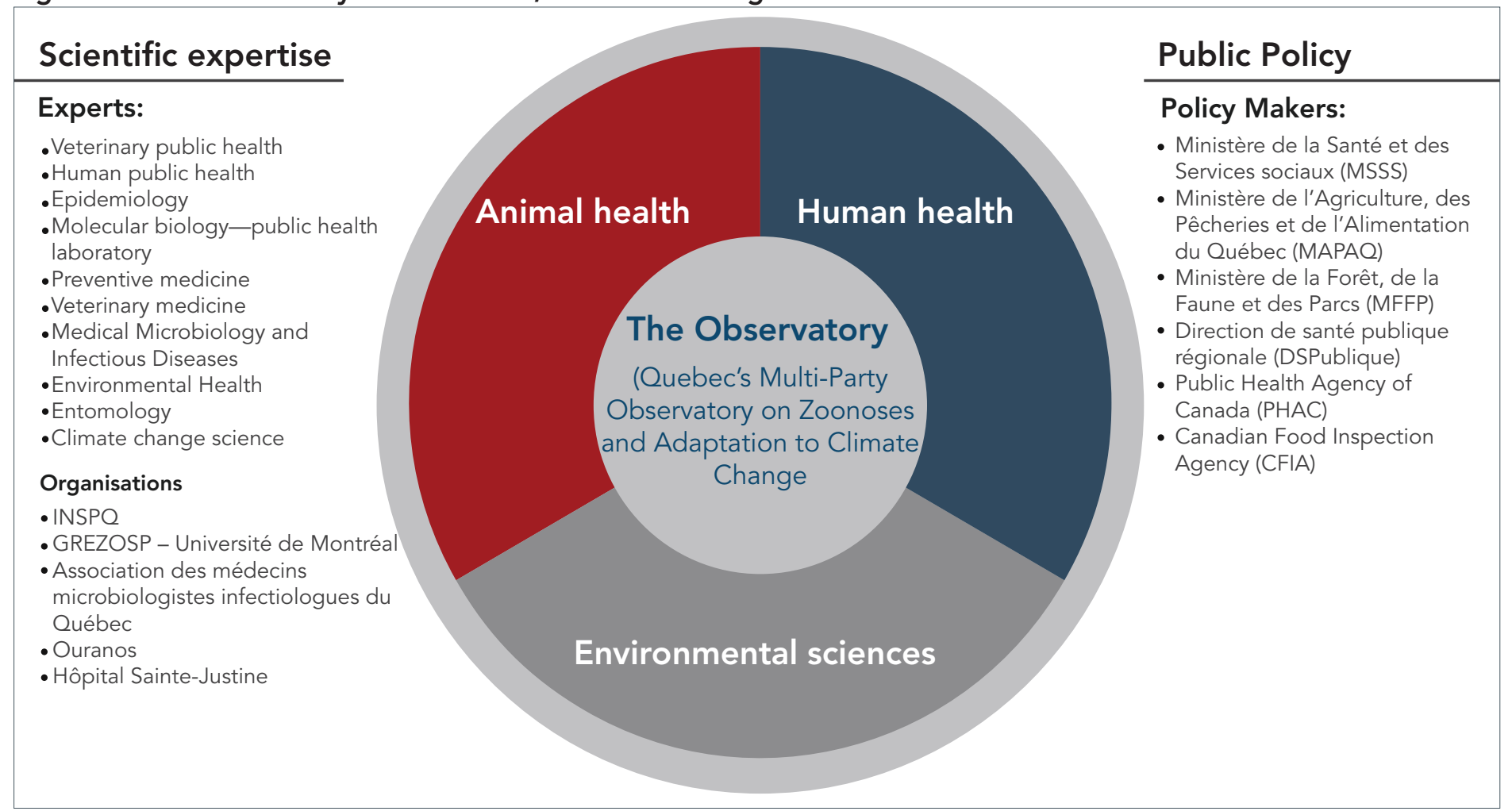

Abbreviations: INSPQ, Institut national de santé publique du Québec; GREZOSP, Groupe de recherche en épidémiologie des zoonoses et en santé publique

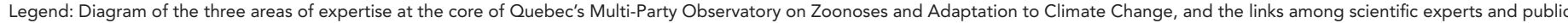
policy decision makers 
The Observatory is managed by the Biological Hazards and Workplace Health Directorate (Direction des risques biologiques et de la santé au travail) of Quebec's National Institute for Public Health [Institut national de santé publique du Québec, (INSPQ)]. The scientific coordination of the Observatory is provided via a partnership between the INSPO and the Faculty of Veterinary Medicine of the University of Montreal, more specifically through the Zoonotic Epidemiology and Public Health Research Group [Groupe de recherche en épidémiologie des zoonoses et en santé publique; (GREZOSP)].

Most members participate solely on a voluntary basis. Two parttime coordinators, who provide operational support and who are responsible for the implementation of the Observatory's action plan, are remunerated. These coordinators also take part in a steering committee that validates their deliverables and operational decisions. There are also participants with relevant expertise in zoonoses and adaptation to climate change who contribute to, or are involved in, the Observatory's activities on an ad hoc basis.

\section{What the Observatory does}

In keeping with its mandate to create ongoing relationships among the scientific and public health authorities who are concerned by zoonoses and the adaptation of zoonoses to climate change in Quebec, and its aim to assess future and existing potential zoonotic infectious diseases, the Observatory:

1. Identifies, anticipates and prioritizes zoonotic and climate change related issues

2. Reports on the evolution of zoonoses, especially by monitoring of scientific literature, official reports, grey literature and current events, as well as information shared by and among members

3. Advises government decision makers regarding concrete actions that can be taken to manage zoonoses

4. Develops products to inform and increase the level of vigilance on zoonoses among members, as well as human health and animal health professionals

\section{Prioritizing zoonotic issues}

Shortly after the Observatory was established, its first initiative was to prioritize knowledge gaps limiting public health actions for the most important zoonoses (13). A report was created based primarily on expert opinion of the Observatory's members and collaborators. The report included a fact sheet on each of the principal zoonotic diseases prioritized by the Observatory, presented in a standardized data summary format; thus, making this information more easily accessible. Recommendations for public health authorities, regarding monitoring, prevention and control activities for the high priority zoonotic diseases, were included (13). These recommendations are used to assess provincial impacts of different zoonoses and to guide provincial public health authorities in their efforts to prioritize initiatives for adapting to climate change. The Observatory report was intended to identify future research areas for both researchers and funding agencies. An English version of this report will be available soon.

A second initiative, which began in 2018, involved a rigorous, transparent and systematic method of prioritization of zoonoses (14). This initiative was based on a multi-criteria decision analysis method (15). This method originated in operational field research and is used by different disciplines to rank options on the basis of both qualitative and quantitative criteria (15). Application of this decision analysis method led to a consensus list of 32 zoonoses, which were classified in order of priority according to their effects on public, animal and environmental health, their socio-economic impacts and their potential emergence or spread due to climate change. This analysis resulted in nine zoonotic diseases classified as "high priority". In descending order, these included West Nile virus infection, botulism, rabies, salmonellosis, listeriosis, Escherichia coli infection, hantavirus pulmonary syndrome, avian flu and Lyme disease (14). Hantavirus pulmonary syndrome and listeriosis fact sheets are currently being developed to complete the published report on prioritized zoonoses by the Observatory (13). An update of the prioritization is planned for every three years.

\section{Monitoring trends}

Another key function of the Observatory is regular scientific and tacit monitoring of the distribution of various zoonoses in Quebec. Scientific monitoring is done by monitoring of scientific literature, official reports, grey literature and current events. Tacit monitoring involves collecting relevant information on zoonoses-related issues from the Observatory members. These activities are done on an ongoing basis and the results are then summarized in the Observatory's annual newsletter.

\section{Collecting and sharing information}

Issues and needs regarding zoonotic diseases are identified through the prioritization process and during the Observatory's meetings, and are then communicated by members and collaborators to their respective networks and organizations. In addition, issues and needs are promoted through the Observatory's publications.

\section{Educating and increasing awareness}

To fulfill its knowledge transfer mandate, the Observatory regularly organizes webinars and conferences on zoonotic emerging issues, such as the arboviruses and enteric zoonoses emerging in Quebec in connection with climate change, or on broader themes such as vulnerabilities to zoonotic diseases in relation to climate change adaptation or ecosystemic approaches to health. The work of the Observatory is summarized in Table 1. 
Table 1: The mandate, activities and actions of the Observatory in Quebec

\begin{tabular}{|c|c|c|c|}
\hline Mandate & Activities & Actions & Examples \\
\hline $\begin{array}{l}\text { Identify and } \\
\text { anticipate possible } \\
\text { zoonotic disease and } \\
\text { climate change issues }\end{array}$ & $\begin{array}{l}\text { Prioritization } \\
\text { exercise }\end{array}$ & $\begin{array}{l}\text { Identifying the most significant zoonotic } \\
\text { diseases in terms of effects on health, socio- } \\
\text { economic impacts and potential emergence } \\
\text { due to climate change } \\
\text { Highlighting the knowledge gaps and related } \\
\text { issues in relation to the prioritized zoonotic } \\
\text { diseases }\end{array}$ & $\begin{array}{l}\text { Prioritization publications: } \\
\text { www.inspq.qc.ca/publications/2432 (French only) } \\
\text { www.inspq.qc.ca/publications/2290 (French only) }\end{array}$ \\
\hline \multirow[t]{2}{*}{$\begin{array}{l}\text { Report on the } \\
\text { evolution of } \\
\text { zoonoses through } \\
\text { monitoring }\end{array}$} & $\begin{array}{l}\text { Scientific } \\
\text { monitoring }\end{array}$ & $\begin{array}{l}\text { Monitoring and providing summaries of } \\
\text { scientific literature, official reports, grey } \\
\text { literature and current events }\end{array}$ & $\begin{array}{l}\text { Newsletter: } \\
\text { www.inspq.qc.ca/zoonoses/observatoire/bulletin (French } \\
\text { only) }\end{array}$ \\
\hline & $\begin{array}{l}\text { Tacit } \\
\text { monitoring }\end{array}$ & $\begin{array}{l}\text { Collecting tacit information and recent } \\
\text { zoonoses-related issues from members during } \\
\text { professional meetings }\end{array}$ & - \\
\hline \multirow[t]{2}{*}{$\begin{array}{l}\text { Communicate the } \\
\text { identified issues and } \\
\text { needs }\end{array}$} & $\begin{array}{l}\text { Issue } \\
\text { identification }\end{array}$ & $\begin{array}{l}\text { Sharing meeting reports and highlighting } \\
\text { monitoring and identified issues within their } \\
\text { organizations }\end{array}$ & $\begin{array}{l}\text { Meeting reports are relayed by the Observatory's } \\
\text { members throughout their respective networks }\end{array}$ \\
\hline & $\begin{array}{l}\text { Circulation of } \\
\text { publications }\end{array}$ & $\begin{array}{l}\text { Drafting a communication plan to promote } \\
\text { the Observatory's publications }\end{array}$ & $\begin{array}{l}\text { Actions in the communication plan include participation } \\
\text { in targeted conferences and promotion through the } \\
\text { INSPQ and GREZOSP webpages }\end{array}$ \\
\hline \multirow[t]{2}{*}{$\begin{array}{l}\text { Develop knowledge- } \\
\text { transfer products }\end{array}$} & Webinars & $\begin{array}{l}\text { Organizing and promoting webinars on } \\
\text { zoonotic emerging issues }\end{array}$ & $\begin{array}{l}\text { Ten webinars on topics such as Lyme disease, Enteric } \\
\text { zoonoses, Ebola in West Africa, monitoring of Aedes } \\
\text { albopictus and modelling studies for mosquito-borne } \\
\text { diseases }\end{array}$ \\
\hline & Conferences & $\begin{array}{l}\text { Organizing conferences for public health } \\
\text { professionals }\end{array}$ & $\begin{array}{l}\text { Three conferences as part of the Annual Public Health } \\
\text { Days (e.g. } 2018 \text { presentation Regional Vulnerabilities } \\
\text { to Zoonoses and Adaptation to Climate Change in } \\
\text { Municipalities) }\end{array}$ \\
\hline
\end{tabular}

\section{Discussion}

With its innovative collaborative structure based on the "One World, One Health" approach, the Observatory enables ongoing assessment of the zoonotic situation in Quebec by including experts from human health, animal health and environmental science sectors. What makes this an innovative model for Canada is that the multi-disciplinary structure also includes the active engagement of agencies involved in formulating public policy.

The development and application of this new model has not been without its challenges. Given its wide range of expertise, there have been challenges to agreeing on definitions, achieving consensus on objectives and reaching common recommendations-especially when these agreements involve people from different disciplines who are new to working under the confines of a virtual multi-disciplinary structure. Thus, the initial projects have taken some time.

With both its strengths and challenges, important progress has already been made and the work of the Observatory will continue. The next major project will be the development of a zoonotic vulnerability assessment methodology. This project is consistent with the World Health Organization's Vulnerability and Adaptation Assessment Guide, which notes that vulnerability assessment is necessary to adapt to climate change (16). However, vulnerability assessment methodology has not yet been adapted to zoonotic issues in Quebec, and will be an important area of focus for the Observatory members.

In addition, an evaluation process has been initiated by Quebec's Ministry of Health and Social Services (Ministère de la Santé et des Services sociaux) to assess the Observatory's performance and implementation. The evaluation will determine how and to what extent the Observatory has fulfilled its mandate and contributed to both short- and medium-term impacts on members, collaborators and target audiences (scientific and academic experts, public health professionals and public policy decision makers). It will assess if collaboration has increased among Observatory's members and to what extent this has contributed to a better understanding of zoonotic issues and the impact of climate change. This evaluation will enable provincial government authorities to direct future actions as necessary. 


\section{Conclusion}

The Observatory is an innovative response to the need to develop adaptive strategies to zoonotic infections that are increasing due to climate change. The Observatory enables collaboration and knowledge transfer among members specializing in human health, animal health and environmental science. By bringing together experts from these different fields and representatives of agencies involved in formulating public policy, the Observatory helps to prioritize, monitor and assess zoonotic issues related to adaptation to climate change. This knowledge transfer is pivotal to increasing Quebec's capacity to deal with the altering landscape of infectious diseases, particularly the alterations associated with climate change.

\section{Authors' statement}

GG - Conceptualization, writing-original draft, review and editing

AS - Conceptualization, writing-original draft, review and editing

JA - Review and editing

GB - Review and editing

CB - Review and editing

DC - Review and editing

FEA - Review and editing

AK - Review and editing

$\mathrm{BL}-$ Review and editing

AM - Review and editing

MM - Review and editing

$\mathrm{NHO}$ - Review and editing

IP - Review and editing

AR - Review and editing

JPR - Review and editing

JS - Review and editing

\section{References}

1. World Health Organization. WHO calls for urgent action to protect health from climate change - Sign the call. (Accessed December 2018). www.who.int/globalchange/globalcampaign/cop21/en/

2. Government of Quebec. The Health Effects of Climate Change. (Accessed February 2019). www.quebec.ca/en/ health/advice-and-prevention/health-and-environment/thehealth-effects-of-climate-change/

3. Lowe AM. Mise sur pied de l'Observatoire. Bulletin de l'Observatoire multipartite québécois sur les zoonoses et I'adaptation aux changements climatiques. 2016;1(1):1. www.inspg.qc.ca/bulletin-de-l-observatoire-multipartitequebecois-sur-les-zoonoses-et-l-adaptation-auxchangements-climatiques/janvier-2016

4. Jones KE, Patel NG, Levy MA, Storeygard A, Balk D, Gittleman JL, Daszak P. Global trends in emerging infectious diseases. Nature 2008 Feb;451(7181):990-3. DOl PubMed

\section{Acknowledgements}

We would like to thank all the members of the Observatory for their commitment and their enthusiasm, and our collaborators for their generous contribution to our work.

\section{Funding}

The Observatory is part of the Government of Quebec's 20132020 Climate Change Action Plan (Plan d'action 2013-2020 sur les changements climatiques), which has a budget that is provided by the Green Fund. The Green Fund, created in 2006, was established under an Act of the Department of Sustainable Development, Environment and Parks (CQLR, chapter M-30.001) to promote Quebec's sustainable development through the protection of the environment, the preservation of biodiversity and the fight against climate change.
5. Belanger D, Berry $P$, Bouchet $V$, Charron D, Clarke KL, Doyon B, Fleury M, Furgal C, Gosselin P, Lamy S, Lindsay LR, McBean G, Ogden N, Séguin J, Schuster CJ, Soskolne CL. Human Health in a Changing Climate: A Canadian Assessment of Vulnerabilities and Adaptive Capacity. Ottawa (ON): Health Canada; 2008. http://publications.gc.ca/ collections/collection_2008/hc-sc/H128-1-08-528E.pdf

6. Ouranos. Towards adaptation: Synthesis on climate change knowledge in Québec (2015 Edition). Montreal (QC): Ouranos, 2015. www.ouranos.ca/en/synthesis-2015/

7. Institute national de santé publique. Groupe d'experts sur les maladies transmises par les tiques, Ouhoummane N, Irace-Cima A, Thivierge K, Milord F. Rapport de surveillance de la maladie de Lyme: 2017. Montréal (OC) : INSPQ, 2018. www.inspq.qc.ca/publications/2472

8. Leighton PA, Koffi JK, Palcat Y, Lindsay LR, Ogden $\mathrm{NH}$. Predicting the speed of tick invasion: an empirical 
model of range expansion for the Lyme disease vector Ixodes scapularis in Canada. Journal of Applied Ecology 2012;49(2):457-64. DOI

9. Ogden NH, Lindsay LR. Effects of Climate and Climate Change on Vectors and Vector-Borne Diseases: Ticks Are Different. Trends Parasitol 2016 Aug;32(8):646-56. DOI PubMed

10. Hellberg RS, Chu E. Effects of climate change on the persistence and dispersal of foodborne bacterial pathogens in the outdoor environment: A review. Crit Rev Microbiol 2016 Aug;42(4):548-72. DOI PubMed

11. Karesh WB, Cook RA. One world--one health. Clin Med (Lond) 2009 Jun;9(3):259-60. DOI PubMed

12. American Veterinary Medical Association. One Health: $A$ New Professional Imperative. One Health Initiative Task Force: Final Report. Schaumburg: American Veterinary Medical Association, 2008. https://www.avma.org/KB/ Resources/Reports/Documents/onehealth_final.pdf

13. Institut national de santé publique du Québec et Université de Montréal. Observatoire multipartite québécois sur les zoonoses et l'adaptation aux changements climatiques. Bouchard C, Lowe AM, Simon A. Portrait des zoonoses priorisées par l'Observatoire multipartite québécois sur les zoonoses et l'adaptation aux changements climatiques en 2015. Montréal (QC) : INSPQ, 2017. https://www. inspq.qc.ca/sites/default/files/publications/2290_portrait_ zoonoses_priorisees_2015.pdf

14. Institut national de santé publique du Québec et Université de Montréal. Observatoire multipartite québécois sur les zoonoses et l'adaptation aux changements climatiques. Simon A, Aenishaenslin C, Hongoh V, Lowe, AM. Priorisation des zoonoses au Québec dans un contexte d'adaptation aux changements climatiques à l'aide d'un outil d'aide à la décision multicritère. Montréal (QC) : INSPQ, 2018. https:// www.inspq.qc.ca/sites/default/files/publications/2432_ priorisation_zoonoses_quebec_outil_aide_decision_ multicritere.pdf

15. World Health Organization. Protecting health from climate change: vulnerability and adaptation assessment. WHO:2013. https://apps.who.int/iris/handle/10665/104200

16. Behzadian M, Kazemzadeh RB, Albadvi A, Aghdasi M. PROMETHEE: A comprehensive literature review on methodologies and applications. European Journal of Operational Research 2010;200(1):198-215. DOI 